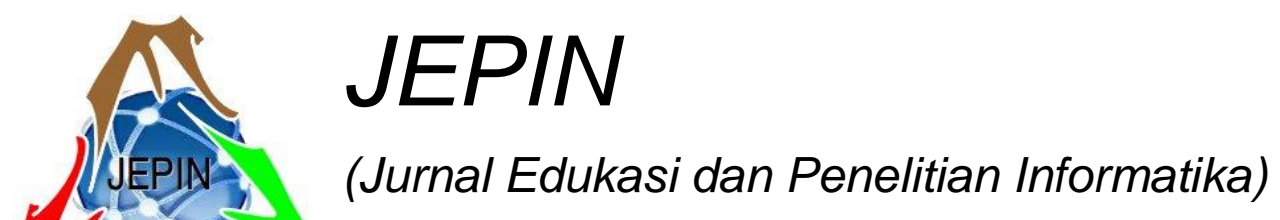

Vol. 6

No. 1

April 2020

ISSN(e): 2548-9364 / ISSN(p) : 2460-0741

\title{
Diagnosis Tahapan Pengguna Narkoba Menggunakan Metode K-Nearest Neighbor
}

\author{
Tursina $^{\# 1}$, Hafiz Muhardi" ${ }^{\# 2}$ Dian Aulia Sari ${ }^{\# 3}$

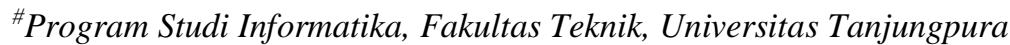 \\ Jl. Prof. Dr. H. Hadari Nawawi, Pontianak 78124 \\ 1tursinaeinformatika.untan.ac.id \\ 2hafiz.muhardieinformatika.untan.ac.id \\ ${ }^{3}$ diianauliasariiegmail.com
}

\begin{abstract}
Abstrak- Narkoba merupakan bahan yang sangat bermanfaat untuk pengobatan, namun jika disalahgunakan akan memberikan dampak buruk yang luar biasa seperti gangguan kesehatan, gangguan kejiwaan hingga kematian. Seorang pengguna narkoba cenderung tertutup dan tidak ingin berkonsultasi langsung ke dokter maupun rehabilitasi dikarenakan pengguna malu dengan kondisinya, biaya yang relatif mahal, jarak dan waktu yang ditempuh, takut dilaporkan dan tanggapan negatif dari masyarakat. Tujuan dilakukannya penelitian ini adalah untuk membantu seorang pengguna narkoba ataupun bagi seseorang yang dicurigai sebagai pengguna narkoba dalam mendiagnosis tahapan pengguna narkoba dan memberikan solusi serta saran terhadap pengguna narkoba tersebut. Case based reasoning merupakan penalaran yang digunakan untuk menyelesaikan kasus baru dengan cara mengadaptasi solusi yang terdapat pada kasus-kasus sebelumnya, yang mempunyai permasalahan yang mirip dengan kasus baru. Pada tahapan retrieve, terjadi proses menghitung similaritas antara kasus baru dan kasus lama. Perhitungan similaritas kasus pada penelitian ini menggunakan metode $\boldsymbol{k}$-nearest neighbor. Pengujian hasil akhir sistem menggunakan pengujian tahapan CBR dan pengujian kinerja metode $k$ nearest neighbor. Hasil pengujian mengukur kinerja dari metode $\boldsymbol{k}$-nearest neighbor dengan nilai $\mathrm{k}=7$, tingkat akurasi untuk 10-fold cross validation sebesar $98,333 \%$, confusion matrix sebesar $100 \%$ dan termasuk excellent classification karena memiliki nilai AUC 1,000.
\end{abstract}

Kata kunci- Tahapan Pengguna Narkoba, Case Based Reasoning, K-Nearest Neighbor, Cross Validation, Confusion Matrix, Kurva ROC.

\section{PEndahuluan}

Ancaman bahaya penyalahgunaan narkoba di Indonesia terus meningkat. Narkoba merupakan singkatan dari Narkotika, Psikotropika dan Bahan Adiktif lainnya. Angka prevalensi penyalahgunaan narkoba di Indonesia pada tahun 2016 secara umum sebesar 2,21\% atau setara dengan 4.173.633 orang. Jenis narkoba yang paling banyak disalahgunakan adalah sabu, ganja dan ekstasi [1].

Narkoba merupakan bahan yang sangat bermanfaat untuk pengobatan, namun jika disalahgunakan akan memberikan dampak buruk yang luar biasa seperti gangguan kesehatan, gangguan kejiwaan hingga kematian. Sebagian besar penyalahgunaan narkoba disebabkan oleh suatu pengaruh, terutama berasal dari teman pergaulan, keluarga dan lingkungan yang berasal dari luar. Penyalahgunaan diawali dengan proses bujukan, tawaran atau tekanan dari teman pergaulan. Didorong rasa ingin tahu atau ingin mencoba seseorang mau menerima dan selanjutnya, dari pemakaian sekali kemudian beberapa kali dan akhirnya menjadi sangat ketergantungan.

Berdasarkan kasus yang pernah ada, didalam diri pengguna memiliki keinginan untuk menggunakan dan juga ingin berhenti/memperbaiki diri dan melawan dari pengaruh buruk narkoba. Namun, seorang pengguna narkoba cenderung tertutup dan tidak ingin berkonsultasi langsung ke dokter maupun rehabilitasi dikarenakan pengguna malu dengan kondisinya, biaya yang relatif mahal, jarak dan waktu yang ditempuh ke tempat rehabilitasi, serta takut dilaporkan dan tanggapan negatif dari masyarakat sekitar. Diagnosis seorang pengguna narkoba dapat dilihat dari ciri-ciri yang tampak dan ditunjukkan dengan adanya perubahan pola hidup dan kesehatan, dari ciri-ciri tersebut dapat dikategorikan ke dalam beberapa tahapan, yaitu tahapan ringan, sedang dan berat.

Case based reasoning merupakan salah satu penalaran yang digunakan dalam pemecahan masalah dengan mencari solusi dari suatu kasus yang baru, sistem akan melakukan pencarian terhadap solusi dari kasus lama yang memiliki permasalahan yang sama dan sudah pernah terjadi sebelumnya. Salah satu tahapan case based reasoning adalah tahapan retrive. Pada tahapan retrieve, terjadi proses menghitung kemiripan antara kasus baru dan kasus lama. Perhitungan similaritas kasus menggunakan metode $k$-nearest neighbor. K-nearest neighbor adalah pendekatan untuk mencari kasus dengan menghitung kedekatan antara kasus baru dan kasus lama yaitu berdasarkan pada pencocokan bobot dari sejumlah fitur yang ada [2]. 
Penelitian tentang case based reasoning dan metode $k$ nearest neighbor dalam menyelesaikan suatu permasalahan, sebelumnya sudah pernah dilakukan oleh beberapa peneliti, salah satunya yaitu Suryanto dkk (2016) dengan judul "Penerapan Case Based Reasoning untuk Mendiagnosa Jenis Pecandu Narkoba". Sistem yang dibangun menggunakan metode K-NN untuk menghitung tingkat kemiripan kasus baru dan kasus lama. Pada penelitian ini jenis pecandu narkoba hanya tiga yaitu, pecandu ganja, pecandu putaw dan pecandu ekstasi. Sistem ini memberikan keluaran berupa kemungkinan jenis pecandu narkoba dan saran terapi yang didasarkan pada kemiripan kasus baru dengan pengetahuan yang dimiliki sistem [3].

Penelitian selanjutnya dilakukan oleh Fatoni dan Noviandha (2017) dengan judul "Case Based Reasoning Diagnosis Penyakit Difteri dengan Algoritma K-Nearest Neighbor". Penelitian ini menggunakan metode K-NN untuk menghitung similaritas pada kasus lama dan kasus baru. Output dari penelitian ini berupa hasil diagnosis penyakit difteri berdasarkan gejala-gejala yang dialami dengan akurasi pengujiannya sebesar 95,17\% [4].

Kemudian, penelitian dilakukan oleh Kurniawan (2017) dengan judul "Implementasi Metode K-Nearest Neighbor (K-NN) Untuk Mengelompokkan Status Ekonomi Masyarakat Desa Kedak Kecamatan Semen”. Pada penelitian ini metode K-NN digunakan untuk mengelompokan status masyarakat miskin, sedang dan kaya berdasarkan kriteria pendapatan, aset dan pengeluaran [5].

\section{URAIAN PENELITIAN}

\section{A. Narkoba}

Istilah narkoba sesuai dengan Surat Edaran Badan Narkotika Nasional (BNN) Nomor: SE/03/IV/2002/BNN merupakan akronim dari narkotika, psikotropika dan bahan adiktif lainnya. Narkoba yaitu zat-zat alami maupun kimiawi yang jika dimasukan ke dalam tubuh dapat mempengaruhi suasana hati dan pikiran seseorang serta dapat merusak susunan syaraf otak [6].

1) Narkotika: Narkotika merupakan zat atau obat yang berasal dari tanaman atau bukan tanaman, baik sintesis maupun semi sintesis, yang dapat menyebabkan penurunan atau perubahan kesadaran, hilangnya rasa, mengurangi sampai menghilangkan rasa nyeri dan dapat menimbulkan ketergantungan [7].

2) Psikotropika: Psikotropika adalah zat atau obat bukan narkotika, baik alamiah maupun sintesis, yang memiliki khasiat psikoaktif melalui pengaruh selektif pada susunan syaraf pusat yang menyebabkan perubahan khas pada aktivitas normal dan perilaku [6].

3) Bahan Adiktif Lainnya: Bahan adiktif lainnya adalah bahan-bahan adiktif atau obat yang dalam organisme hidup menimbulkan kerja biologi yang apabila disalahgunakan dapat menimbulkan ketergantungan (adiksi), yaitu keinginan untuk menggunakan kembali secara terus menerus [6].
Penggunaan terus menerus dan berlanjut akan menyebabkan ketergantungan atau kecanduan. Pengguna narkoba terbagi menjadi tiga tahapan, yaitu:

1. Pengguna Tahap Ringan

a) Pengguna Coba-Coba (Experimental Use)

Pada tahap ini, pengguna hanya terpengaruh terhadap lingkungan sekitar dan memakai narkoba hanya sekedar ingin tahu dan merasakan narkoba itu sendiri, pernah sekali atau beberapa kali mencoba memakai narkoba dalam waktu relatif singkat untuk kemudian berhenti.

b) Pengguna Sosial/Rekreasi (Recreational Use) Pada tahap ini, penggunaan dilakukan saat berkumpul atau pada acara tertentu agar diakui atau diterima kelompoknya.

2. Pengguna Tahap Sedang

Pengguna tahap sedang meliputi pengguna tahap situasional (situasional use). Pada tahap ini, pengguna biasanya menggunakan pada situasi dan keadaan tertentu, biasanya untuk mengurangi perasaan tidak enak terutama rasa nyeri, cemas, kekecewaan, kesedihan dan kemurungan.

3. Pengguna Tahap Berat

a) Pengguna Intensif Bermasalah (Intensive Use)

Pada tahap ini, pengguna memakai narkoba secara patologis setiap hari dalam satu bulan terakhir sehingga menimbulkan gangguan fungsi sosial dan pekerjaan.

b) Pengguna Tahap Ketergantungan (Compulsive Dependent Use)

Pada tahap ini, pengguna sudah sulit untuk menghentikan penggunaan narkoba karena sudah terjadi adiksi yang berlangsung lama dan terjadi ketergantungan baik berupa fisik maupun psikis.

\section{B. Case Based Reasoning}

Case based reasoning merupakan salah satu penalaran yang digunakan dalam pemecahan masalah dengan mencari solusi dari suatu kasus yang baru, sistem akan melakukan pencarian terhadap solusi dari kasus lama yang memiliki permasalahan yang sama dan sudah pernah terjadi sebelumnya. Kasus baru dicocokkan dengan kasuskasus yang ada didalam basis data penyimpanan kasus (case base) dan menemukan satu atau lebih kasus yang mirip. Jika kasus baru mempunyai kemiripan dengan kasus lama, maka CBR akan menggunakan kembali (reuse) solusi kasus lama sebagai rekomendasi solusi kasus baru tersebut. Tetapi jika tidak ada yang cocok maka CBR akan melakukan adaptasi, dengan cara memasukkan/menyimpan (retain) kasus baru tersebut ke dalam basis data kasus, sehingga secara tidak langsung pengetahuan CBR akan bertambah [8].

Komponen penyelesaian masalah CBR memiliki dua bagian utama, yaitu case retriever dan case reasoner. Case retriever bertugas untuk mencari masalah-masalah yang mirip dengan masalah yang dimasukkan pengguna didalam basis pengetahuan (case base), sementara case reasoner bertugas untuk mencari solusi masalah pengguna 
dengan melihat atau menyesuaikan solusi masalah yang ditemukan case retriever [9].

Terdapat empat tahapan pada case based reasoning, yaitu [9]:

1) Retrieve: yaitu mendapatkan kasus-kasus yang mirip dengan kumpulan kasus pada basis kasus. Pada tahapan ini dilakukan proses pencarian dan perhitungan similaritas dari kasus-kasus yang memiliki kemiripan.

2) Reuse: yaitu menggunakan kembali informasi dan pengetahuan dari kasus yang lama untuk mengatasi kasus baru. Pada tahapan ini dicari solusi dari kasus lama yang serupa untuk permasalahan baru.

3) Revise: yaitu mengubah dan mengadopsi solusi yang ditawarkan jika perlu. Pada tahapan ini meninjau kembali solusi yang diberikan untuk permasalahan yang terjadi kemudian.

4) Retain: yaitu proses menyimpan pengetahuan untuk memecahkan masalah yang akan datang ke dalam basis kasus. Pada tahap ini terjadi suatu proses penggabungan dari solusi kasus yang baru ke knowledge yang telah ada.

Tahapan case based reasoning dapat dilihat pada Gambar 1.

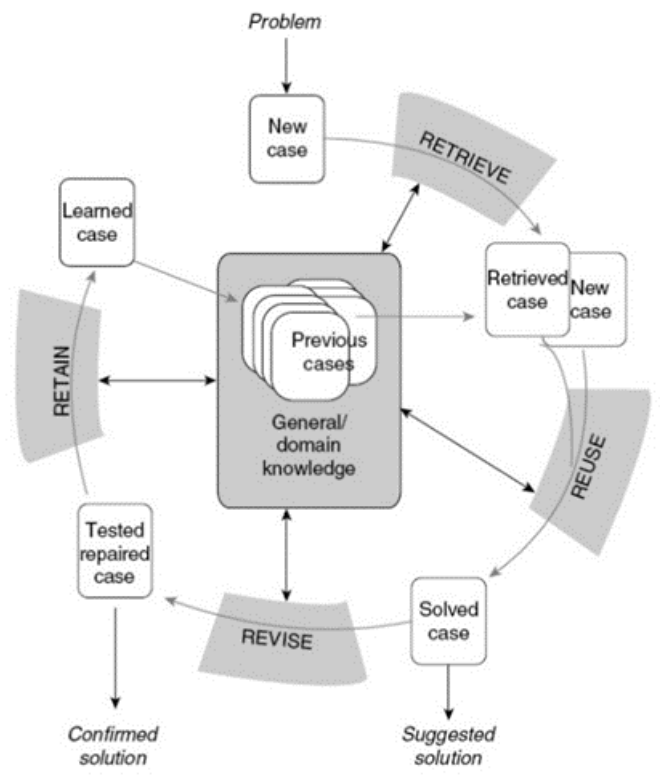

Gambar. 1 Tahapan case based reasoning

\section{K-Nearest Neighbor}

K-nearest neighbor (K-NN) termasuk kelompok instance based learning. K-nearest neighbor adalah pendekatan untuk mencari kasus dengan menghitung kedekatan antara kasus baru dan kasus lama yaitu berdasarkan pada pencocokan bobot dari sejumlah fitur yang ada [2]. K-NN memiliki atribut yang diinisialisasikan sebagai $k$, yaitu jumlah nilai tetangga yang dijadikan acuan pada klasifikasi, berupa bilangan bulat positif, berjumlah kecil dan ganjil. Nilai $k$ yang optimal dapat dipilih dengan optimasi parameter, misalnya dengan menggunakan cross validation [10]
Pada penalaran case based reasoning terdapat tahapan retrieve. Pada tahapan retrieve, K-NN digunakan untuk menghitung kemiripan antara kasus lama dan kasus baru. Untuk mengetahui ukuran kedekatan antara kasus lama (x) dan kasus baru (y) maka digunakan rumus euclidean, seperti yang ditunjukkan pada persamaan 1 .

$$
D(x, y)=\sqrt{\sum_{k=1}^{n}\left(x_{k}-y_{k}\right)^{2}}
$$

Rumus untuk menghitung bobot kemiripan (similarity) adalah seperti yang ditunjukkan persamaan 2 [9].

$$
\text { Similarity } \left._{(\text {baru,lama }}\right)=\frac{\sum_{i=1}^{n} \text { function }_{\left(\text {Baru }_{i} \text { Lama }_{i}\right) \text { weight }_{i}}}{\sum_{i=1}^{n} \text { weight }_{i}}
$$

Tahapan dari klasifikasi menggunakan metode K-NN adalah sebagai berikut:

1. Menentukan parameter $k$ dengan menggunakan cross validation. Akurasi dari berbagai nilai $k$ dapat dilihat pada Tabel 3.

2. Menghitung kuadrat jarak antara kasus lama dan kasus baru menggunakan euclidean distance yang direpresentasikan pada persamaan 1. Perhitungan jarak bertujuan untuk mengetahui ukuran kedekatan antara kasus lama dan kasus baru. Setelah menghitung jarak, dilakukan perhitungan similaritas antara kasus lama dan kasus baru menggunakan persamaan 2 .

3. Kemudian mengurutkan hasil perhitungan tersebut dari jarak terkecil sampai jarak terbesar (ascending). Langkah ini dilakukan untuk mengelompokkan nilai $k$ yang digunakan.

4. Penentuan prediksi kelas pada kasus baru didasarkan pada label kelas mayoritas kasus lama pada kelompok nilai $k$ dan kasus lama yang memiliki kemiripan paling besar dengan kasus baru.

Contoh perhitungan menggunakan metode $k$-nearest neighbor dengan ciri-ciri pengguna seperti: mengalami gangguan tidur (F1), mengalami gangguan penglihatan seperti mata merah, gatal, pupil mengecil/membesar (F3), mengalami mual dan muntah $(\mathrm{F} 4)$, mengelami penurunan berat badan (F6), mengalami kesukaran mengontrol perilaku kasar, termasuk kemarahan atau kekerasan (F9).

$\mathrm{Kn}=[1,0,1,1,0,1,0,0,1,0,0,0,0,0,0,0,0,0]$

$\mathrm{K} 1=[1,0,1,1,0,1,1,0,1,0,0,0,0,0,0,0,0,0]$

Perhitungan kasus baru dengan jarak terdekat pertama dengan menggunakan persamaan 1 .

$\mathrm{D}(\mathrm{Kn}, \mathrm{K} 1)=\sqrt{\begin{array}{c}(1-1)^{2}+(0-0)^{2}+(1-1)^{2}+(1-1)^{2}+(0-0)^{2}+ \\ (1-1)^{2}+(1-0)^{2}+(0-0)^{2}+(1-1)^{2}+(0-0)^{2}+ \\ (0-0)^{2}+(0-0)^{2}+(0-0)^{2}+(0-0)^{2}+ \\ (0-0)^{2}+(0-0)^{2}+(0-0)^{2}+(0-0)^{2}\end{array}}$
$\mathrm{D}(\mathrm{Kn}, \mathrm{K} 1)=\sqrt{\begin{array}{l}(0)^{2}+(0)^{2}+(0)^{2}+(0)^{2}+(0)^{2}+(0)^{2}+ \\ (1)^{2}+(0)^{2}+(0)^{2}+(0)^{2}+(0)^{2}+(0)^{2}+\end{array}}$
$\mathrm{D}(\mathrm{Kn}, \mathrm{K} 1)=\sqrt{\begin{array}{cc}0+0+0+0+0+0+1+0+0+0+ \\ 0+0+0+0+0+0+0+0\end{array}}$
$\mathrm{D}(\mathrm{Kn}, \mathrm{K} 1)=\sqrt{1 \quad}$
$\mathrm{D}(\mathrm{Kn}, \mathrm{K} 1)=1$


Perhitungan similaritas dengan menggunakan persamaan 2.

$$
\left.\operatorname{Similarity}_{\text {baru,lama }}\right)=\frac{\sum_{i=1}^{n} \text { function }_{\left(\text {Baru }_{i} \text { Lama }_{i}\right) \text { weight }_{i}}}{\sum_{i=1}^{n} \text { weight }_{i}}
$$

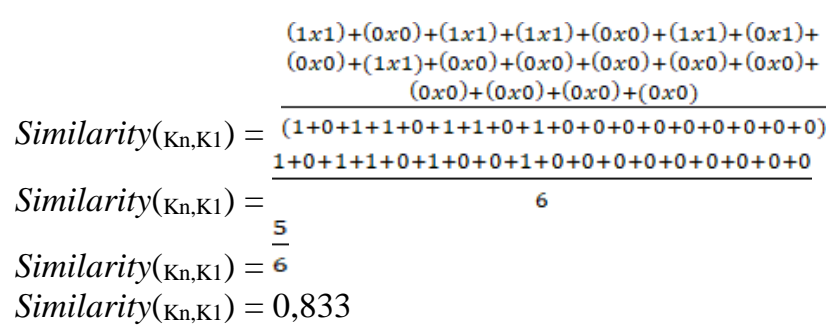

\section{Unified Modeling Language (UML)}

Unified modeling language merupakan bahasa visual untuk pemodelan dan komunikasi mengenai sistem dengan menggunakan diagram dan teks-teks pendukung [11].

1) Use Case Diagram: Use case mendeskripsikan sebuah interaksi antara satu atau lebih aktor dengan sistem informasi yang akan dibuat [11].

2) Activity Diagram: Activity diagram (diagram aktivitas) menggambarkan workflow (aliran kerja) atau aktivitas dari sebuah sistem atau proses bisnis [11].

3) Sequence Diagram: Sequence diagram adalah diagram interaksi yang menekankan pada pengiriman pesan dalam suatu waktu tertentu [11]

4) Class Diagram: Class diagram menggambarkan struktur sistem dari segi pendefinisian kelas-kelas yang akan dibuat untuk membangun sistem [11].

\section{E. WEKA (Waikato Environment for Knowledge Analysis)}

WEKA adalah sebuah paket tools machine learning praktis untuk preprocessing data, klasifikasi, regresi, clustering, aturan asosiasi dan visualisasi [12]. Pada penelitian ini, dilakukan pengukuran akurasi untuk membuktikan tingkat performa suatu metode terhadap dataset yang digunakan menggunakan alat bantu aplikasi WEKA. Seluruh basis kasus dan kasus uji diubah menjadi format .csv untuk pengolahan data pada aplikasi WEKA. Data akan diolah dengan menggunakan metode $k$-nearest neighbor dan menghasilkan model. Model yang dihasilkan tersebut dilakukan pengujian menggunakan cross validation, kemudian dilakukan evaluasi dan validasi hasil dengan confusion matrix dan kurva ROC.

\section{F. Pengujian Kinerja Metode K-Nearest Neighbor}

Klasifikasi merupakan suatu pekerjaan menilai objek data untuk memasukannya ke dalam kelas tertentu dari sejumlah kelas yang tersedia. Sistem dalam klasifikasi diharapkan mampu melakukan klasifikasi semua data dengan benar, namun tidak dapat dipungkiri bahwa kesalahan akan terjadi dalam proses pengklasifikasian sehingga perlunya dilakukan pengukuran kinerja dari sistem klasifikasi tersebut [13].

\section{G. Cross Validation}

Cross validation merupakan salah satu teknik untuk menilai/memvalidasi keakuratan sebuah model yang dibangun berdasarkan dataset tertentu. Salah satu metode cross validation adalah $k$-fold cross validation. Pada $k$ fold cross validation penggunaan jumlah fold terbaik untuk uji validitas, dianjurkan menggunakan 10-fold cross validation dalam model [14]. Tahap pengujian dengan menggunakan metode 10-fold cross validation membagi basis data yang berjumlah 60 data akan dibagi menjadi 10 subset (bagian), masing-masing subset berjumlah 6 data. Pada fold pertama terdapat kombinasi 9 subset yang berbeda digabung dan digunakan sebagai basis kasus, sedangkan 1 subset (sisa) digunakan sebagai kasus uji, selanjutnya proses pengujian dilakukan sampai fold kesepuluh. Hasil uji akurasi dengan metode 10-fold cross validation dapat dilihat pada Tabel 5.

\section{H. Confusion Matrix}

Model yang telah dibentuk akan diuji tingkat akurasinya dengan memasukkan kasus uji ke dalam model. Kasus uji memiliki 15 sampel yang akan diujikan ke dalam basis kasus untuk mendapatkan hasil klasifikasi dari metode k-nearest neighbor. Akurasi dari kinerja model klasifikasi didasarkan pada banyaknya kasus uji yang dapat diprediksi secara benar dan tidak benar oleh model yang ditabulasikan dalam sebuah tabel Confusion Matrix. Confusion matrix adalah tabel yang dipergunakan sebagai alat ukur yang berguna untuk melakukan analisis seberapa baik pengklasifikasian benar dan salah dari prediksi yang dilakukan dalam kelas-kelas yang berbeda [15].

\section{Kurva ROC}

Kurva ROC (Receiver Operating Characteristic) mengekspresikan confusion matrix. Pada pengujian ini, terdapat tiga klasifikasi yaitu klasifikasi tahapan ringan, tahapan sedang dan tahapan berat. Penentuan model yang terbaik dilihat dari luas di bawah kurva ROC atau AUC (Area Under Curve). Metode yang memiliki AUC lebih besar merupakan metode yang lebih baik. Menurut Gorunescu, nilai AUC dapat dibagi menjadi beberapa kelompok [15]:

- $\quad 0,900-1,000=$ Excellent Classification

- $0,800-0,900=$ Good Classification

- $0,700-0,800=$ Fair Classification

- $0,600-0,700=$ Poor Classification

- $0,500-0,600=$ Failure

\section{PERANCANGAN SISTEM}

\section{A. Perancangan Arsitektur Sistem}

Desain arsitektur diagnosis tahapan pengguna narkoba dapat dilihat pada Gambar 2. 


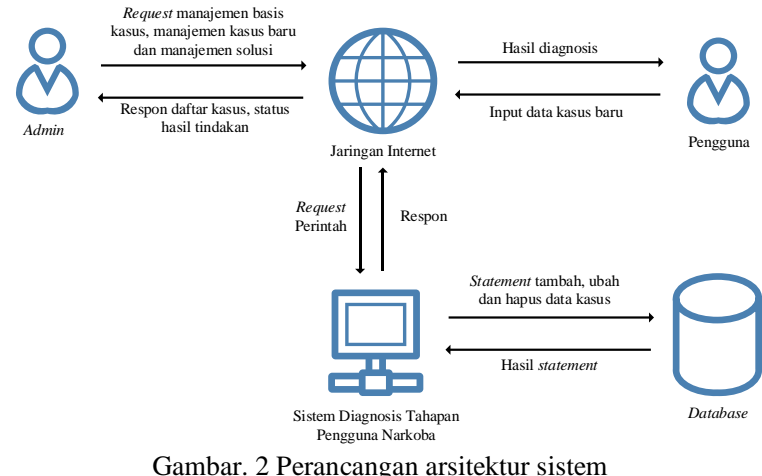

\section{B. Perancangan Fitur}

Fitur yang digunakan dalam mendiagnosis tahapan pengguna narkoba adalah berdasarkan ciri-ciri pengguna narkoba. Perancangan fitur dapat dilihat pada Tabel 1.

TABEL I

PERANCANGAN FITUR
C. Perancangan Diagram Alir

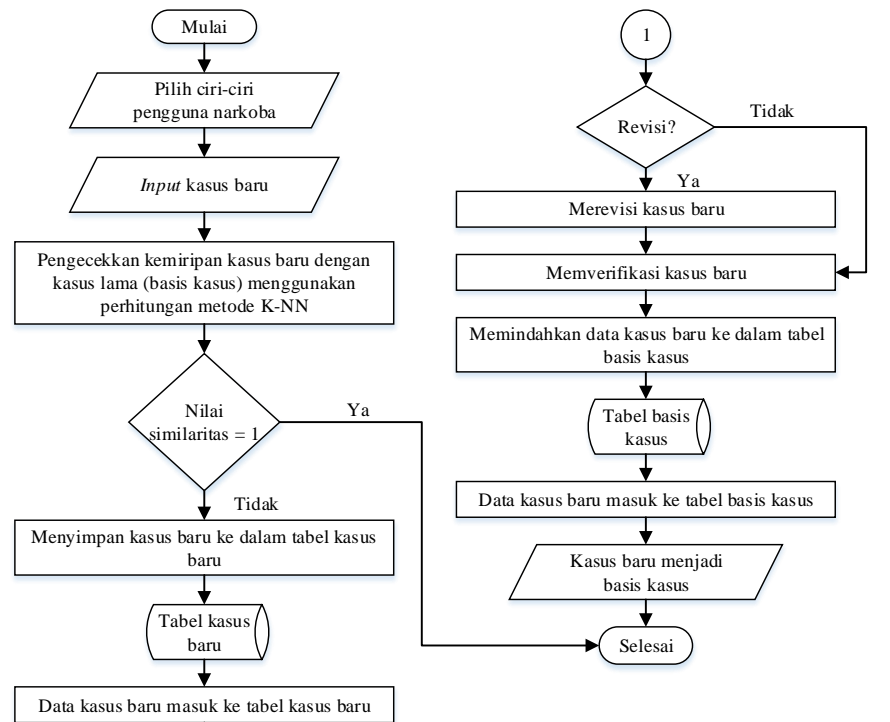

\begin{tabular}{|c|c|c|}
\hline No. & $\begin{array}{c}\text { Kode } \\
\text { Ciri }\end{array}$ & Ciri-Ciri Pengguna Narkoba \\
\hline 1. & F1 & Mengalami gangguan tidur \\
\hline 2. & F2 & $\begin{array}{l}\text { Mengalami gangguan penglihatan seperti mata } \\
\text { merah, gatal, pupil mengecil/membesar }\end{array}$ \\
\hline 3. & F3 & Mengalami kesulitan bernafas \\
\hline 4. & F4 & Mengalami mual dan muntah \\
\hline 5. & F5 & Merasa pusing dan sakit kepala \\
\hline 6. & F6 & Mengalami penurunan berat badan \\
\hline 7. & F7 & $\begin{array}{l}\text { Mengalami kesulitan mengingat atau fokus pada } \\
\text { sesuatu }\end{array}$ \\
\hline 8. & F8 & $\begin{array}{l}\text { Mengalami perubahan suasana hati yang signifikan } \\
\text { seperti gembira yang berlebihan, kesedihan, putus } \\
\text { asa dan kehilangan minat }\end{array}$ \\
\hline 9. & F9 & $\begin{array}{l}\text { Mengalami kesukaran mengontrol perilaku kasar, } \\
\text { termasuk kemarahan atau kekerasan }\end{array}$ \\
\hline 10. & F10 & $\begin{array}{l}\text { Timbul masalah kulit di sekitar mulut, hidung, dan } \\
\text { perubahan warna muka seperti gatal-gatal, bibir } \\
\text { pecah-pecah, dan terkelupas }\end{array}$ \\
\hline 11. & F11 & $\begin{array}{l}\text { Mengalami gejala radang paru-paru, seperti sesak } \\
\text { nafas, saat batuk nyeri di paru-paru }\end{array}$ \\
\hline 12. & F12 & $\begin{array}{l}\text { Mengalami gejala kerusakan hati, lambung, dan } \\
\text { ginjal seperti nyeri dibagian hati, lambung, dan } \\
\text { ginjal, nyeri saat buang air kecil }\end{array}$ \\
\hline 13. & F13 & $\begin{array}{l}\text { Pingsan sering terjadi disaat pengguna berkeinginan } \\
\text { untuk mengkonsumsi narkoba }\end{array}$ \\
\hline 14. & F14 & $\begin{array}{l}\text { Mengalami rasa cemas serius atau ketegangan seperti } \\
\text { gelisah dan khawatir berlebihan }\end{array}$ \\
\hline 15. & F15 & $\begin{array}{l}\text { Mengalami halusinasi seperti melihat dan mendengar } \\
\text { sesuatu yang tidak ada objeknya }\end{array}$ \\
\hline 16. & F16 & Berusaha untuk bunuh diri \\
\hline 17. & F17 & $\begin{array}{l}\text { Tekanan darah menurun, sering mengalami lemas, } \\
\text { mata cekung }\end{array}$ \\
\hline 18. & F18 & $\begin{array}{l}\text { Otot-otot menjadi lemas dan mulai mengalami } \\
\text { kelumpuhan berjalan, berdiri, dan tidak mampu } \\
\text { berkomunikasi }\end{array}$ \\
\hline
\end{tabular}

Gambar. 3 Diagram alir diagnosis tahapan pengguna narkoba

Diagram alir diagnosis tahapan pengguna narkoba dimulai dengan memilih ciri-ciri yang dirasakan kemudian sistem akan melakukan pengecekkan kemiripan kasus baru dan kasus lama menggunakan perhitungan metode K-NN. Jika nilai similaritas sama dengan 1, maka proses selesai. Jika nilai similaritas tidak sama dengan 1, maka kasus baru akan disimpan ke dalam tabel kasus baru. Tabel kasus baru menyimpan seluruh data kasus baru yang di input pengguna. Kemudian kasus baru tersebut dapat di revisi dan retain kasus baru ke dalam basis kasus. Basis kasus akan digunakan sebagai acuan solusi atas kasus baru lainnya.

\section{ANALISIS HASIL}

\section{A. Hasil Perancangan Sistem}

Halaman konsultasi merupakan halaman yang dapat diakses oleh pengunjung saat ingin melakukan konsultasi untuk mendiagnosis tahapan pengguna narkoba. Antarmuka halaman konsultasi dapat dilihat pada Gambar 4

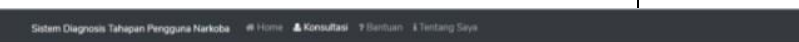

\& Diagnosis Kasus

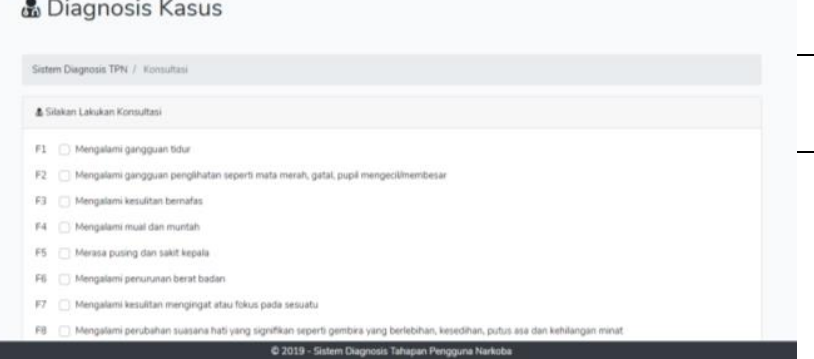

Gambar 4. Antarmuka halaman konsultasi 


\section{B. Hasil Pengujian}

1) Pengujian Akurasi Nilai K: Kinerja metode KNN dengan nilai $k$ optimal akan menghasilkan akurasi ketepatan prediksi lebih tinggi. Hasil akurasi dari masingmasing nilai $k$ dapat dilihat pada Tabel 2 .

TABEL II

AKURASI K-NN DARI BERBAGAI NILAI K

\begin{tabular}{|c|c|}
\hline Nilai $\boldsymbol{K}$ & Akurasi \\
\hline 1 & $93,333 \%$ \\
\hline 3 & $95 \%$ \\
\hline 5 & $95 \%$ \\
\hline 7 & $98,333 \%$ \\
\hline 9 & $98,333 \%$ \\
\hline 11 & $98,333 \%$ \\
\hline
\end{tabular}

Berdasarkan Tabel 3 menunjukkan bahwa akurasi terus mengalami kenaikan pada rentang nilai $k=1$ sampai $k=7$ dan cenderung stabil sampai nilai $k=13$. Nilai $k=7$ ditetapkan sebagai nilai $k$ yang optimal dengan tingkat akurasi sebesar $98,333 \%$.

2) Pengujian Tahapan Case Based Reasoning

a) Tahapan retrieve adalah untuk menelusuri dan mendapatkan kasus-kasus yang mirip dalam basis kasus dengan kasus baru. Proses didalam tahapan retrieve, yaitu:

Melakukan input data dan mendiagnosis tahapan pengguna narkoba pada Gambar 5.

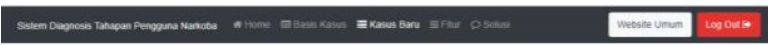

$\therefore$ Diagnosis Kasus

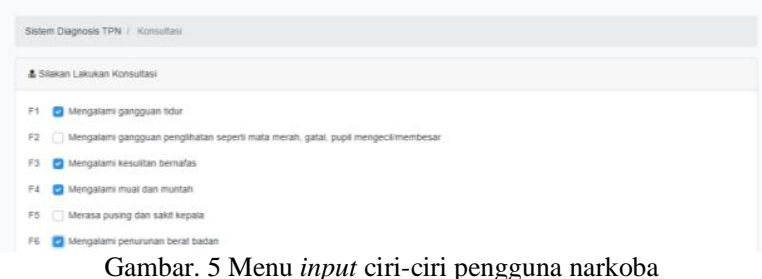

Mencari tingkat kemiripan dengan menggunakan metode k-nearest neighbor antara kasus baru dengan kasus-kasus yang ada didalam basis kasus pada Gambar 6.

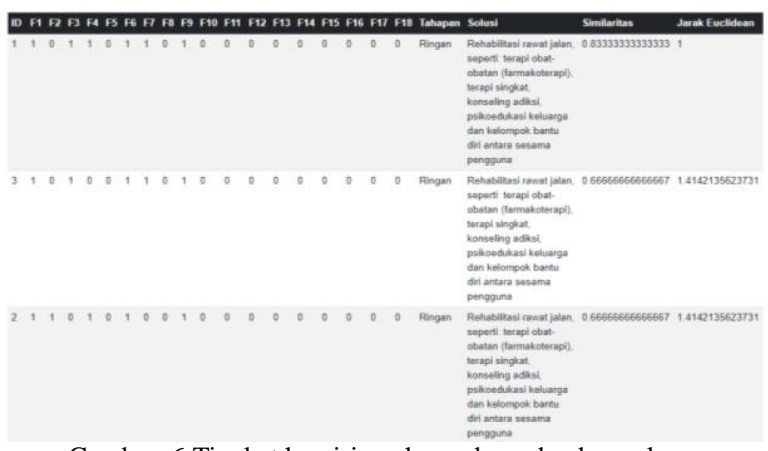

Gambar. 6 Tingkat kemiripan kasus baru dan kasus lama

b) Tahapan reuse adalah menggunakan kembali kasus-kasus yang ada dan dicoba untuk menyelesaikan suatu kasus baru yang ditunjukkan pada Gambar 7. Tahapan ini memberikan output yang dihasilkan dari perhitungan metode K-NN yaitu diagnosis dan solusi.

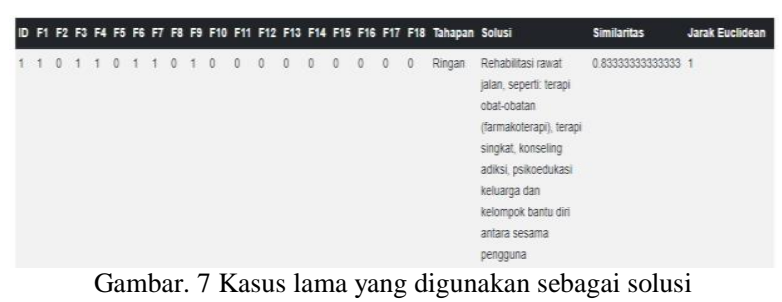

c) Tahapan revise adalah meninjau kembali solusi yang telah didapatkan dari kasus yang lama apakah solusi tersebut akan diterapkan pada kasus baru atau solusi tersebut perlu diperbaiki terlebih dahulu. Tahapan revise ditunjukkan pada Gambar 8.

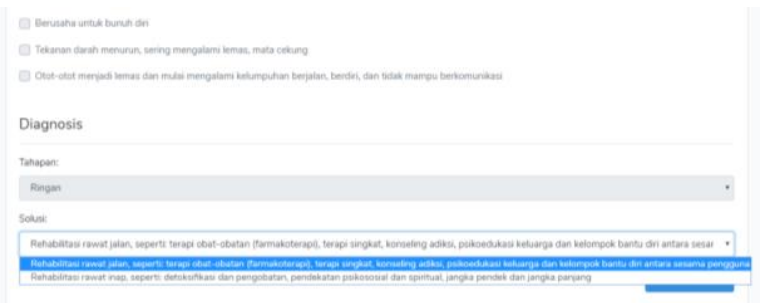

Gambar. 8 Halaman revise solusi kasus baru

d) Tahapan retain dilakukan dengan memindahkan data kasus baru ke basis kasus yang ditunjukkan pada Gambar 9.
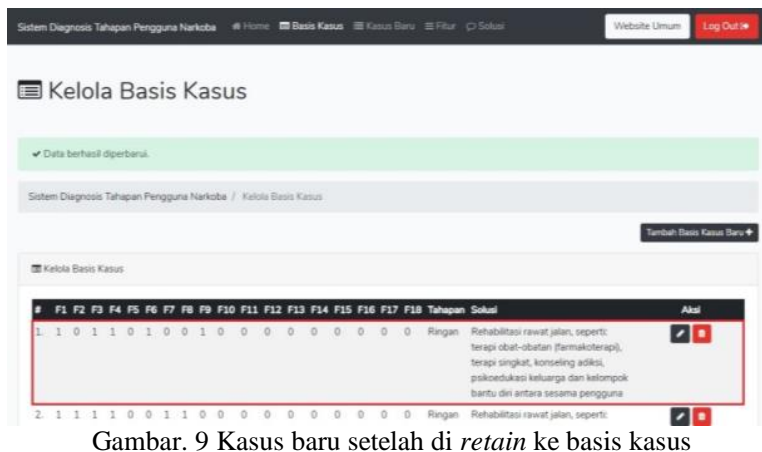

3) Pengujian Kinerja Metode K-Nearest Neighbor a) Cross Validation

Pada skenario uji dengan jumlah 10-fold cross validation, rata-rata yang dihasilkan yaitu $98,333 \%$. Hasil akurasi pengujian dapat dilihat pada Tabel 3.

b) Confusion Matrix

Hasil evaluasi confusion matrix dalam klasifikasi menunjukkan tingkat akurasi seperti yang ditunjukkan pada Gambar 10. Perhitungan kedekatan kasus lama pada basis kasus dengan kasus baru pada kasus uji, diketahui dari 15 data, semua data class diklasifikasikan sesuai dimana 5 data diklasifikasikan ringan, 5 data diklasifikasikan sedang dan 5 data diklasifikasikan berat. 
TABEL III

HASIL AKURASI 10-FOLD CROSS VALIDATION

\begin{tabular}{|c|c|c|c|}
\hline Fold & Data & Subset & Akurasi \\
\hline \multirow[t]{2}{*}{ Fold 1} & $\begin{array}{l}\text { Basis Kasus = } \\
54\end{array}$ & $\begin{array}{l}\mathrm{S}_{2}, \mathrm{~S}_{3}, \mathrm{~S}_{4}, \mathrm{~S}_{5}, \mathrm{~S}_{6}, \\
\mathrm{~S}_{7}, \mathrm{~S}_{8}, \mathrm{~S}_{9}, \mathrm{~S}_{10} .\end{array}$ & \multirow{2}{*}{$100 \%$} \\
\hline & Kasus $\mathrm{Uji}=6$ & $S_{1}$ & \\
\hline \multirow{2}{*}{ Fold 2} & $\begin{array}{l}\text { Basis Kasus = } \\
54\end{array}$ & $\begin{array}{l}S_{1}, S_{3}, S_{4}, S_{5}, S_{6}, \\
S_{7}, S_{8}, S_{9}, S_{10} .\end{array}$ & \multirow{2}{*}{$100 \%$} \\
\hline & Kasus $\mathrm{Uji}=6$ & $\mathrm{~S}_{2}$ & \\
\hline \multirow{2}{*}{ Fold 3} & $\begin{array}{l}\text { Basis Kasus = } \\
54\end{array}$ & $\begin{array}{l}\mathrm{S}_{1}, \mathrm{~S}_{2}, \mathrm{~S}_{4}, \mathrm{~S}_{5}, \mathrm{~S}_{6}, \\
\mathrm{~S}_{7}, \mathrm{~S}_{8}, \mathrm{~S}_{9}, \mathrm{~S}_{10} .\end{array}$ & \multirow[t]{2}{*}{$100 \%$} \\
\hline & Kasus Uji $=6$ & $\mathrm{~S}_{3}$. & \\
\hline \multirow[t]{2}{*}{ Fold 4} & $\begin{array}{l}\text { Basis Kasus = } \\
54\end{array}$ & $\begin{array}{l}\mathrm{S}_{1}, \mathrm{~S}_{2}, \mathrm{~S}_{3}, \mathrm{~S}_{5}, \mathrm{~S}_{6}, \\
\mathrm{~S}_{7}, \mathrm{~S}_{8}, \mathrm{~S}_{9}, \mathrm{~S}_{10} .\end{array}$ & \multirow[t]{2}{*}{$83,333 \%$} \\
\hline & Kasus $\mathrm{Uji}=6$ & $\mathrm{~S}_{4}$ & \\
\hline \multirow[t]{2}{*}{ Fold 5} & $\begin{array}{l}\text { Basis Kasus = } \\
54\end{array}$ & $\begin{array}{l}\mathrm{S}_{1}, \mathrm{~S}_{2}, \mathrm{~S}_{3}, \mathrm{~S}_{4}, \mathrm{~S}_{6}, \\
\mathrm{~S}_{7}, \mathrm{~S}_{8}, \mathrm{~S}_{9}, \mathrm{~S}_{10} .\end{array}$ & \multirow[t]{2}{*}{$100 \%$} \\
\hline & Kasus Uji $=6$ & $\mathrm{~S}_{5}$ & \\
\hline \multirow[t]{2}{*}{ Fold 6} & $\begin{array}{l}\text { Basis Kasus = } \\
54\end{array}$ & $\begin{array}{l}\mathrm{S}_{1}, \mathrm{~S}_{2}, \mathrm{~S}_{3}, \mathrm{~S}_{4}, \mathrm{~S}_{5}, \\
\mathrm{~S}_{7}, \mathrm{~S}_{8}, \mathrm{~S}_{9}, \mathrm{~S}_{10 .}\end{array}$ & \multirow[t]{2}{*}{$100 \%$} \\
\hline & Kasus $\mathrm{Uji}=6$ & $\begin{array}{ll}S_{6} . \\
\end{array}$ & \\
\hline \multirow[t]{2}{*}{ Fold 7} & $\begin{array}{l}\text { Basis Kasus = } \\
54\end{array}$ & $\begin{array}{l}\mathrm{S}_{1}, \mathrm{~S}_{2}, \mathrm{~S}_{3}, \mathrm{~S}_{4}, \mathrm{~S}_{5}, \\
\mathrm{~S}_{6}, \mathrm{~S}_{8}, \mathrm{~S}_{9}, \mathrm{~S}_{10} .\end{array}$ & \multirow[t]{2}{*}{$100 \%$} \\
\hline & Kasus $\mathrm{Uji}=6$ & $\mathrm{~S}_{7 .}$ & \\
\hline \multirow[t]{2}{*}{ Fold 8} & $\begin{array}{l}\text { Basis Kasus = } \\
54\end{array}$ & $\begin{array}{l}\mathrm{S}_{1}, \mathrm{~S}_{2}, \mathrm{~S}_{3}, \mathrm{~S}_{4}, \mathrm{~S}_{5}, \\
\mathrm{~S}_{6}, \mathrm{~S}_{7}, \mathrm{~S}_{9}, \mathrm{~S}_{10} .\end{array}$ & \multirow[t]{2}{*}{$100 \%$} \\
\hline & Kasus $\mathrm{Uji}=6$ & $\mathrm{~S}_{8 .}$ & \\
\hline \multirow[t]{2}{*}{ Fold 9} & $\begin{array}{l}\text { Basis Kasus = } \\
54\end{array}$ & $\begin{array}{l}\mathrm{S}_{1}, \mathrm{~S}_{2}, \mathrm{~S}_{3}, \mathrm{~S}_{4}, \mathrm{~S}_{5}, \\
\mathrm{~S}_{6}, \mathrm{~S}_{7}, \mathrm{~S}_{8}, \mathrm{~S}_{10} . \\
\end{array}$ & \multirow[t]{2}{*}{$100 \%$} \\
\hline & Kasus Uji $=6$ & $\mathrm{~S}_{9 .}$ & \\
\hline \multirow{2}{*}{$\begin{array}{c}\text { Fold } \\
10\end{array}$} & $\begin{array}{l}\text { Basis Kasus = } \\
54\end{array}$ & $\begin{array}{l}\mathrm{S}_{1}, \mathrm{~S}_{2}, \mathrm{~S}_{3}, \mathrm{~S}_{4}, \mathrm{~S}_{5}, \\
\mathrm{~S}_{6}, \mathrm{~S}_{7}, \mathrm{~S}_{8}, \mathrm{~S}_{9} . \\
\end{array}$ & \multirow[t]{2}{*}{$100 \%$} \\
\hline & Kasus Uji $=6$ & $\mathrm{~S}_{10}$ & \\
\hline \multicolumn{3}{|c|}{ Rata-Rata Akurasi } & $98,333 \%$ \\
\hline
\end{tabular}

$$
\begin{aligned}
& ==\text { Confusion Matrix }=== \\
& \begin{array}{lllll}
\mathrm{a} & \mathrm{b} & \mathrm{c} & <-- \text { classified as } \\
5 & 0 & 0 & \mid \mathrm{a}=\text { Ringan } \\
0 & 5 & 0 & \mid \mathrm{b}=\text { Sedang } \\
0 & 0 & 5 & \mid & \mathrm{c}=\text { Berat }
\end{array}
\end{aligned}
$$

Gambar. 10 Model confusion matrix untuk k-nearest neighbor

Perhitungan akurasi dengan confusion matrix terhadap metode $k$-nearest neighbor adalah sebagai berikut:

$$
\begin{aligned}
& \text { Akurasi }=\frac{T P+T N}{T P+T N+F P+F N} \\
& \text { Akurasi }=\frac{5+5+5}{5+5+5+0+0+0+0+0+0} \\
& \text { Akurasi }=\frac{15}{15} \\
& \text { Akurasi }=1
\end{aligned}
$$

Persentase akurasi penerapan algoritma $k$-nearest neighbor sebesar $1 \times 100 \%=100 \%$.

\section{c) Kurva ROC}

Hasil perhitungan divisualisasikan dengan kurva ROC dan hasilnya dapat dilihat pada Gambar 11 terdapat nilai Weighted Average sebesar 1,000 yang disebut nilai AUC (Area Under Curve). Menurut pembagian kelompok klasifikasi Gorunescu, maka dapat disimpulkan bahwa metode k-nearest neighbor untuk mendiagnosis tahapan pengguna narkoba termasuk excellent classification karena memiliki nilai AUC sebesar 1,000.

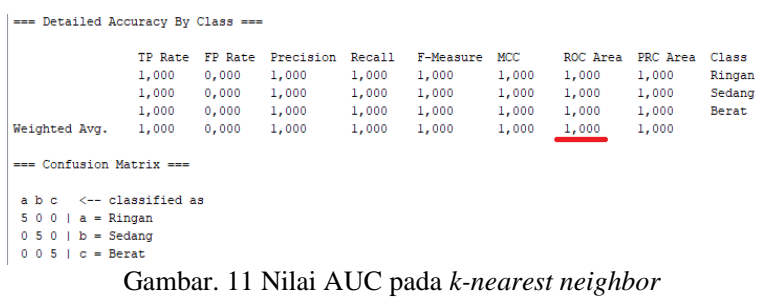

\section{Analisis Hasil}

Analisis hasil pengujian diagnosis tahapan pengguna narkoba dapat disimpulkan sebagai berikut:

1. Nilai $\mathrm{k}=7$ merupakan nilai $k$ yang optimal dengan tingkat akurasi sebesar $98,333 \%$.

2. Hasil pengujian menunjukkan bahwa keseluruhan dari tahapan case based reasoning dapat dilakukan, yaitu tahapan retrieve, tahapan reuse, tahapan revise dan tahapan retain.

3. Pengujian kinerja dari metode k-nearest neighbor dengan menggunakan aplikasi WEKA, tingkat akurasi untuk cross validation sebesar 98,333\%, confusion matrix sebesar $100 \%$ dan termasuk excellent classification karena memiliki nilai AUC 1,000.

\section{KESIMPULAN}

Berdasarkan hasil analisis dan pengujian terhadap diagnosis tahapan pengguna narkoba, dapat disimpulkan:

1. Berdasarkan hasil pengujian bahwa penalaran case based reasoning dengan metode k-nearest neighbor dapat mendiagnosis dan memberikan tingkatan tahapan pengguna narkoba.

2. Berdasarkan hasil pengujian, keseluruhan tahapan case based reasoning dapat dilakukan yaitu tahapan retrieve (mendapatkan kasus-kasus yang mirip), tahapan reuse (menggunakan kembali kasus-kasus yang ada dan mencoba untuk menyelesaikan kasus sekarang), tahapan revise (mengubah dan mengadopsi solusi yang ditawarkan jika perlu) dan tahapan retain (menggunakan solusi baru sebagai bagian dari kasus baru, kemudian kasus baru diperbaharui ke dalam basis kasus).

3. Pengujian metode k-nearest neighbor dengan menggunakan aplikasi WEKA, tingkat akurasi untuk cross validation sebesar 98,333\%, confusion matrix sebesar $100 \%$ dan termasuk excellent classification karena memiliki nilai AUC 1,000. 


\section{REFERENSI}

[1] Kementerian Kesehatan RI. 2017. Anti Narkoba Sedunia. Jakarta: InfoDATIN.

[2] Wicaksana, P. D. 2015. Perbandingan Algoritma K-Nearest Neighbors Dan Naive Bayes Untuk Studi Data "Wisconsin Diagnosis Breast Cancer". Skripsi. Jurusan Teknik Informatika. Fakultas Sains dan Teknologi. Universitas Sanata Dharma Yogyakarta.

[3] Suryanto, A. A., Imron R., Miftahul U. dan Andi W. 2016. Penerapan Case Based Reasoning (CBR) untuk Mendiagnosa Jenis Pecandu Narkoba. Seminar Nasional Ilmu (SNIK), pp. 315319.

[4] Fatoni, C. S. dan Friandy D. N. 2017. Case Based Reasoning Diagnosis Penyakit Difteri dengan Algoritma K-Nearest Neighbor. Creative Information Technology Journal, Vol. 4, No. 3, pp. 220232.

[5] Kurniawan, P. 2017. Implementasi Metode K-Nearest Neighbor (K-NN) Untuk Mengelompokkan Status Ekonomi Masyarakat Desa Kedak Kecamatan Semen. Simki-Techsain, Vol. 01, No. 06.

[6] Partodiharjo, S. 2010. Kenali Narkoba dan Musuhi Penyalahgunaannya. Jakarta: Erlangga.

[7] Badan Narkotika Nasional. 2012. Mahasiswa dan Bahaya Narkotika. Jakarta: Badan Narkotika Nasional Republik Indonesia.

[8] Faizal, E. 2014. Case Based Reasoning Diagnosis Penyakit Cardiovascular Dengan Metode Simple Matching Coefficient Similarity. Jurnal Teknologi Informasi dan Ilmu Komputer (JTIIK), Vol. 1, No. 2, pp. 83-90.

[9] Chandra, R., Kestrilia R. P. dan Paulus L. T. I. 2014 Implementasi Case Based Reasoning pada Fitur Rekomendasi Nakamnakam.com Berbasis Android di Kota Malang. Jurnal Ilmiah Nasional, Vol. 1, No. 1, pp. 1-12.

[10] Banjarsari, M. A., Irwan B. dan Andi F. 2015. Penerapan KOptimal Pada Algoritma K-NN Untuk Prediksi Kelulusan Tepat Waktu Mahasiswa Program Studi Ilmu Komputer Fmipa Unlam Berdasarkan IP Sampai Dengan Semester 4. KLIK-Kumpulan Jurnal Ilmu Komputer, Vol. 2, No. 2, pp. 159-173.

[11] Shalahudin M. dan Rosa A. S. 2013. Rekayasa Perangkat Lunak Terstruktur dan Berorientasi Objek. Bandung: Informatika.

[12] Purnamasari D., Jonathan H., Yoga P. S., Fuji I. dan I Wayan S. W. 2013. Get Easy Using WEKA. Jakarta Timur: Dapur Buku.

[13] Arifin, T. Implementasi Metode K-Nearest Neighbor Untuk Klasifikasi Citra Sel Pap Smear Menggunakan Analisis Tekstur Nukleus. Jurnal Informatika, Vol. 2, No. 1, pp. 287-295.

[14] Pitria, P. 2014. Analisis Sentimen Pengguna Twitter Pada Akun Resmi Samsung Indonesia Dengan Menggunakan Nä̈ve Bayes. Jurnal Ilmiah Komputer dan Informatika (KOMPUTA), pp. 1-8.

[15] Prasetio, R. T. dan Pratiwi. 2015. Penerapan Teknik Bagging Pada Algoritma Klasifikasi Untuk Mengatasi Ketidakseimbangan Kelas Dataset Medis. Jurnal Informatika, Vol. II, No. 2, pp. 395 403 . 